Kemampuan Menulis Karangan Narasi ....(Liza Murniviyanti)

\title{
KEMAMPUAN MENULIS KARANGAN NARASI DENGAN MENGGUNAKAN MODEL THINK TALK WRITE (TTW) DAN MEDIA GAMBAR PADA SISWA SMP DI SUMATERA SELATAN
}

\author{
Oleh: Liza Murniviyanti \\ (Dosen Universitas PGRI Palembang) \\ Email: murniviyantiliza@gmail.com
}

\begin{abstract}
Abstrak
Tujuan penelitian ini untuk mendeskripsikan pengaruh model pembelajaran Think Talk Write (TTW) dalam menulis karangan deskripsi siswa Kelas VIII MTs Nurul Hilal Senuro. Metode penelitian yang digunakan adalah metode eksperimen. Sampel penelitian berjumlah 37 orang (18 orang laki-laki dan 19 orang perempuan). Berdasarkan kriteria pengujian hipotesis, $t_{\text {hitung }}$ dengan nilai 12,19 lebih besar dibandingkan dengan $t_{\text {tabel }}$ dengan nilai 1,70. Teknik pengumpulan data, yaitu teknik tes dan teknik wawancara, hal ini didukung dengan hasil wawancara guru bahwa guru Bahasa Indonesia sudah mengajarkan materi menulis karangan deskripsi dan menggunakan metode latihan, metode ceramah, metode tanya jawab, dan metode diskusi, selalu memberikan latihan di saat mengajar menulis karangan deskripsi karena dengan latihan dapat mengetahui kemampuan menulis karangan deskripsi siswa. Teknik analisis data dalam penelitian ini menggunakan uji-t, sehingga ada pengaruh model pembelajaran Think Talk Write (TTW) dalam Menulis Karangan Deskripsi Siswa Kelas VIII MTs Nurul Hilal Senuro.
\end{abstract}

Kata Kunci: Think Talk Write (TTW), Menulis Karangan Deskripsi

\section{WRITING ABILITY OF NARRATIVE DISORDERS USING THINK TALK WRITE (TTW) MODEL AND IMAGING MEDIA IN STUDENTS OF SMP IN SOUTH SUMATERA}

\begin{abstract}
The purpose of this study was to describe the effect of the Think Talk Write (TTW) learning model in writing descriptions of students of Class VIII MTs Nurul Hilal Senuro. The research method used is the experimental method. The study sample amounted to 37 people (18 men and 19 women). Based on the criteria of testing the hypothesis that $t_{-}$(count) with a value of 12.19 is greater than $t_{-}$ (table) with a value of 1.70. Data collection techniques, namely test techniques and interview techniques, this is supported by the results of teacher interviews that Indonesian language teachers have taught writing essay writing material and using training methods, lecture methods, question and answer methods, and discussion methods, always providing training in teaching write a description essay because with the practice of knowing the ability to write a description of students' essays. While the data analysis techniques in this study used the t-test, so
\end{abstract}


Wahana Didaktika Vol. 18 No.1 Januari 2020 : 15-32

that there was an influence of the Think Talk Write (TTW) learning model in Writing Description of Class VIII Students at MTs Nurul Hilal Senuro.

Keywords: Think Talk Write (TTW), Writing Authorship Description

\section{A. PENDAHULUAN}

Pendidikan merupakan suatu proses dalam rangka mempengaruhi peserta didik supaya mampu menyesuaikan diri sebaik mungkin dengan lingkungannya, dan demikian akan menimbulkan perubahan dalam dirinya yang memungkinkannya untuk berfungsi dalam kehidupan masyarakat (Hamalik, 2015:3). Tujuan pendidikan adalah seperangkat hasil pendidikan yang tercapai oleh peserta didik setelah diselenggarakannya kegiatan pendidikan. Seluruh kegiatan pendidikan, yakni bimbingan pengajaran,dan latihan diarahkan untuk mencapai tujuan pendidikan. Ada empat komponen keterampilan bahasa yang harus diketahui yaitu menyimak, berbicara, membaca dan menulis. Keterampilan itu berhubungan erat pula dengan proses-proses berfikir yang mendasari bahasa. Bahasa seseorang mencerminkan pikirannya, semakin terampil seseorang berbahasa semakin cerah dan jelas pula jalan pikirannya.

Keterampilan menulis merupakan bagian dari keterampilan berbahasa Indonesia yang harus dimiliki oleh siswa. Untuk memiliki keterampilan mengarang yang baik dituntut pengetahuan mengenai kaidah penulisan, latihan terus menerus, dan pengetahuan mengenai pembentukan kata dan penyusunan kalimat, serta pengembangan paragraf. Pada saat menulis semua ide dan gagasan tertuang dalam kata dan kalimat menggunakan ejaan yang benar. Menulis merupakan suatu kegiatan komunikasi berupa penyamaian pesan secara tertulis kepada pihak lain dengan menggunakan bahasa tulis sebagai alat atau medianya (Dalman, 2016:3).

Salah satu kompetensi dasar yang terdapat dalam standar isi bahasa Indonesia Sekolah Menengah Pertama (SMP) adalah menulis. Tujuan kompetensi dasar menulis, materi pokok menulis karangan deskripsi adalah agar siswa 
mampu mendeskripsikan apa yang dialami atau dilihatnya dan mampu menuangkannya dalam bahasa tulis atau lisan secara tersusun.

Untuk mencapai tujuan pendidikan, tidak terlepas dari kegiatan pembelajaran di kelas. Mengajar adalah proses membimbing kegiatan belajar dan kegiatan mengajar hanya bermakna bila terjadi kegiatan belajar siswa. Oleh karena itu, penting sekali bagi setiap guru memahami sebaik-baiknya tentang proses belajar siswa agar ia dapat memberikan bimbingan dan menyediakan lingkungan belajar yang tepat dan serasi bagi siswa.

Satu inovasi menarik yang mengiringi perubahan dari sistem pengajaran dan pembelajaran menulis adalah ditemukan dan diterapkanya model pembelajaran. Salah satunya yaitu model pembelajaran Think Talk Write (TTW) yang dengan tepat mampu mengembangkan dan menggali pengetahuan siswa secara konkret dan mandiri terhadap materi ajar khususnya menulis karangan deskripsi. Model pembelajaran Think Talk Write (TTW) adalah strategi yang memfasilitasi latihan berbahasa secara lisan dan menulis bahasa tersebut dengan lancar (Huda, 2016:218).

Berkaitan dengan permasalahan di atas, penelitian ini untuk memberikan solusi penggunaan model Think Talk Write (TTW) dalam menyampaikan materi menulis karangan deskripsi siswa Sekolah Menengah Pertama. Di samping itu, peneliti melakukan penelitian untuk melihat sejauh mana Pengaruh Model Pembelajaran Think Talk Write (TTW) terhadap Kemampuan Menulis Karangan Deskripsi Siswa Kelas VIII MTs Nurul Hilal Senuro.

Berdasarkan uraian di atas, maka peneliti beranggapan bahwa penelitian ini perlu dilakukan untuk mengetahui pengaruh model pembelajaran Think Talk Write $(T T W)$ terhadap kemampuan menulis karangan deskripsi siswa kelas VIII MTs Nurul Hilal Senuro, bahwa masih banyak siswa yang kurang mampu dalam menulis karangan terutama karangan deskripsi.

Peneliti menetapkan objek atau tempat penelitian MTs Nurul Hilal Senuro berdasarkann alasan dan pertimbangan: (1) meskipun MTs Nurul Hilal Senuro berstatus SMP swasta, namun berdasarkan informasi dari guru dan siswa. Pada 
observasi awal, kemampuan siswa menulis karangan deskripsi belum memadai; (2) siswa kelas VIII MTs Nurul Hilal Senuro sudah mempelajari cara-cara menulis karangan deskripsi; (3) perlu adanya penelitian mengenai keefektifan suatu model pembelajaran yang digunakan oleh guru bahasa Indonesia di MTs Nurul Hilal Senuro guna mengetahui efektifitas model pembelajaran yang digunakan oleh guru di sekolah tersebut.

Model pembelajaran Think Talk Write (TTW) adalah strategi yang memfasilitasi latihan berbahasa secara lisan dan menulis bahasa tersebut dengan lancar. Sedangkan strategi Think Talk Write (TTW) adalah untuk mendorong siswa berfikir, berbicara, dan kemudian menuliskan suatu topik tertentu. Strrategi ini digunakan untuk mengembangkan tulisan dengan lancar dan melatih bahasa sebelum dituliskan dan memperkenankan siswa untuk mempengaruhi dan memanipulasi ide-ide sebelum menuangkannya dalam bentuk tulisan.

Menurut Huda (2016:219) langkah-langkah model pembeljaran Think Talk Write (TTW) sebagai berikut.

1. Siswa membaca teks dan membuat catatan dari hasil bacaan secara individu untuk di bawah ke forum diskusi.

2. Siswa berinteraksi dan berkolaborasi dengan teman satu grup untuk membahas isi catatan. Dalam kegiatan ini mereka menggunakan bahasa dan kata-kata mereka sendiri untuk menyampaikan ide-ide matematika dalam diskusi. Pemahaman dibangun melalui interaksi dalam diskusi, karena itu diskusi diharapkan dapat menghasilkan solusi atas soal yang diberikan.

3. Siswa mengkonstruksi sendiri pengetahuan yang memuat pemahaman dan komunikasi matematika dalam tulisan.

4. Kegiatan akhir pembelajaran membuat refleksi dan kesimpulan atas materi yang dipelajari. Sebelum itu, dipilih satu atau beberapa orang siswa sebagai perwakilan kelompok untuk menyajikan jawaban, sedangkan kelompok lain diminta memberikan tanggapan.

Dalam bidang karang mengarang, deskripsi dimaksudkan sebagai suatu karangan yang digunakan penulis untuk memindahkan kesan-kesannya, 
Kemampuan Menulis Karangan Narasi ....(Liza Murniviyanti)

memindahkan hasil pengamatan dan perasaannya, dan disajikan kepada para pembaca. Sasaran yang ingin dicapai oleh penulis deskripsi adalah menciptakan atau memungkinkan terciptanya daya khayal para pembaca, seolah-olah pembaca mengalaminya sendiri. Deskripsi adalah suatu bentuk karanan yang melukiskan sesuatu sesuai dengan keadaan sebenarnya, sehingga pembaca dapat mencitrai (melihat, mendengar, mencium dan merasakan) apa yang dilukiskan itu sesuai dengan citra penulisnya (Dalman, 2014:94).

\section{B. METODOLOGI PENELITIAN}

Mahsun (2012:72) mengemukakan, "Metode adalah cara penelitian yang akan dilakukan yang di dalamnya mencakup bahasa atau materi penelitian, alat, jalan penelitian, variabel dan data yang disediakan serta analisis data. Metode ini digunakan untuk mengetahui bagaimana sebenarnya keefektifan model Think Talk Write (TTW) terhadap kemampuan siswa kelas VIII MTs Nurul Hilal Senuro menulis karangan deskripsi. Metode eksperimen ini diterapkan dalam bentuk belajar-mengajar terhadap dua kelompok sampel yang sama karakteristiknya, yaitu kelompok sampel ekperimen dan kelompok kontrol sebagai sampel pembanding dengan menggunakan 1 jam pelajaran bahasa Indonesia di kelas VIII MTs Nurul Hilal Senuro.

Arikunto (2014:173-174), "Populasi adalah keseluruhan subjek penelitian. Maka dalam penelitian ini yang menjadi populasi adalah seluruh siswa kelas VIII MTs Nurul Hilal Senuro yang berjumlah 78 orang. Sampel adalah sebagian atau wakil populasi yang diteliti dan dianggap mewakili seluruh populasi ini. Dalam penelitian ini yang menjadi sampel adalah dua kelas yaitu kelas VIII.A dan kelas VIII.D.

\section{HASIL PENELITIAN DAN PEMBAHASAN}

Pada tes menulis karangan deskripsi, siswa kelas VIII.C MTs Nurul Hilal Senuro (siswa kelas eksperimen) dan siswa kelas VIII.D MTs Nurul Hilal Senuro (siswa kelas kontrol) pada tes akhirnya diminta untuk mendeskripsikan 
lingkungan sekolah. Panjang karangan untuk tes akhir terdiri atas 5-6 paragraf, yang berisi paragrapf pembuka, isi, dan penutup. Waktu yang disediakan untuk tes adalah 90 menit ( 2 x 45 menit) atau 2 jam pelajaran.

Sebelum melaksanakan penelitian, peneliti mengobservasi siswa dan sampel penelitian di MTs Nurul Hilal Senuro. Dalam penelitian ini, peneliti menggunakan metode eksperimen dengan desain eksperimen Posstes-Only Control Design. Dalam desain ini terdapat dua kelompok yang masing-masing dipilih secara random (R). kelompok pertama (kelas eksperimen) diberi perlakuan yaitu menerapkan metode Think Talk Write (TTW) dalam menulis karangan deskripsi dan kelompok lain tidak diberi perlakuan atau disebut kelas kontrol.

Dalam penelitian ini, peneliti melaksanakan pembelajaran pada tanggal 24 dan 25 Juli 2017 di kelas kontrol serta pada tanggal 27 dan 28 Juli 2017 di kelas eksperimen. Masing-masing sebanyak 2 kali pertemuan di kelas eksperimen dan kelas kontrol dengan waktu yang tersedia 4 x 40 menit, dalam 1 kali perbelajaran dan 1 kali pertemuan untuk tes.

Berdasarkan hasil perhitungan dengan menggunakan rumus uji-t diketahui bahwa $t_{\text {hitung }}=12,19$. Hal ini berarti bahwa model pembelajaran Think Talk Write $(T T W)$ memiliki pengaruh yang positif terhadap kemampuan menulis karangan deskripsi dan pengaruh tersebut memiliki taraf nyata signifikan 0,05 yang berarti bahwa hubungannya signifikan (nyata) $\mathrm{dk}=n_{1}+n_{2}-2,20+15-2=33$ dalam $t_{\text {tabel }}=1,70$ dari hasil perhitungan didapat $t_{\text {tabel }}<t_{\text {hitung }}=1,70<12,19$, sehingga $t_{\text {hitung }}$ dinyatakan signifikan. Dengan demikian $H_{0}$ ditolak dan $H_{a}$ diterima.

\section{PEMBAHASAN}

Dari hasil analisis data penelitian yang dilakukan oleh peneliti dengan cara menyuruh siswa menulis karangan deskripsi, bahwa siswa kelas eksperimen yang menggunakan model pembelajaran Think Talk Write (TTW) dalam menulis karangan deskripsi yang mendapatkan hasil yang lebih baik dibandingkan dengan hasil belajar siswa pada kelas kontrol yang tidak menggunakan model 
pembelajaran Think Talk Write (TTW) dalam menulis karangan deskripsi. Hal ini diketahui dari nilai rata-rata siswa kelas eksperimen yaitu 82,75 , sedangkan nilai rata-rata kelas kontrol yaitu 63,6. Berdasarkan hasil nilai tes tersebut diperoleh bahwa nilai kelompok eksperimen lebih tinggi dibandingkan dengan nilai kelompok kontrol.

Langkah selanjutnya menghitung hasil uji normalitas data eksperimen dan kontrol, bahwa hasil uji normalitas data eksperimen yaitu -0,20 sedangkan hasil uji normalitas data kontrol yaitu -0,41. Langkah selanjutnya melakukan uji homogenitas, bahwa sampel yang ada diperoleh dari populasi yang homogen ini dibuktikan bahwa $F_{\text {hitung }}<F_{\text {tabel }}=1,67<2,23$. Langkah selanjutnya melakukan uji hipotesis dengan menggunakan uji-t diperoleh $t_{\text {hitung }}=12,19$, pada taraf signifikan 0,05 dengan db 33 yaitu 1,70. Sehingga $t_{\text {tabel }}<t_{\text {hitung }}=1,70<12,19$, sehingga $\mathrm{H}_{0}$ ditolak dan $\mathrm{H}_{\mathrm{a}}$ diterima, artinya ada pengaruh yang signifikan model pembelajaan Think Talk Write (TTW) dalam menulis karangan deskripsi siswa kelas VIII MTs Nurul Hilal Senuro.

Berdasarkan hasil penelitian tersebut di atas hipotesis yang diajukan terbukti kebenarannya bahwa ada pengaruh yang signifikan model pembelajaan Think Talk Write (TTW) dalam menulis karangan deskripsi siswa kelas VIII MTs Nurul Hilal Senuro. Hal ini juga didukung oleh hasil wawancara guru bahwa Guru Bahasa Indonesia MTs Nurul Hilal Senuro sudah mengajarkan materi menulis karangan deskripsi dan menggunakan metode latihan, metode ceramah, metode tanya jawab, dan metode diskusi, selalu memberikan latihan di saat mengajar menulis karangan deskripsi karena dengan adanya latihan dapat mengetahui kemampuan menulis karangan deskripsi siswa, dan apabila ada yang yang mengalami kesulitan dalam menerima pembelajaran yang diberikan khususnya materi tentang menulis karangan deskripsi maka guru menjelaskan kembali materi tentang bagaimana cara menulis karangan deskripsi yang baik dan benar dan memberikan latihan.

Hasil penelitian ini menunjukkan bahwa model pembelajran Think Talk Write $(T T W)$ terhadap kemampuan menulis karangan deskripsi siswa kelas VIII 
MTs Nurul Hilal Senuro mempengaruhi hasil belajar. Oleh karena itu model pembelajaran Think Talk Write (TTW) dapat diterapkan dalam pembelajaran bahasa Indonesia.

\section{SIMPULAN}

Berdasarkan hasil deskripsi data, analisis data dan pembahasan pada bab IV, dapat ditarik kesimpulan. Hasil rata-rata kelas eskperimen yaitu kelas yang diberikan pembelajaran dengan menggunakan model pembelajaran Think Talk Write $(T T W)$ mendapatkan nilai rata-rata sebesar 82,75, sedangkan kelas kontrol yaitu kelas tanpa perlakuan 63,6. Berdasarkan fakta tersebut, diperoleh bahwa kelompok eksperimen lebih tinggi dibandingkan dengan kelompok kontrol.

Berdasarkan kriteria pengujian hipotesis bahwa Ho diterima jika $t_{\text {hitung }}<t_{\text {tabel }}$ dan Ha diterima jika $t_{\text {hitung }}>t_{\text {tabel. }}$ Oleh karena itu, $t_{\text {hitung }}$ dengan nilai 12,19 lebih besar dibandingkan $t_{\text {tabel }}$ dengan nilai 1,70 sehingga ada pengaruh model pembelajaran Think Talk Write (TTW) dalam menulis karangan deskripsi siswa kelas VIII MTs Nurul Hilal Senuro.

\section{DAFTAR PUSTAKA}

Arikunto, Suharsimi. (2014). Prosedur Penelitian Suatu Pendekatan Praktik. Jakarta: Rineka Cipta.

Dalman. (2014). Keterampilan Menulis. Jakarta: Raja Grafindo Persada

Dalman. (2016). Keterampilan Menulis. Jakarta: PT. Rajagrafindo Persada.

Hamalik, Oemar. (2015). Kurikulum dan Pembelajaran. Jakarta: Bumi Aksara.

Huda, Miftahul. (2016). Model-model Pengajaran dan Pembelajaran. Yogyakarta: Pustaka Pelajar.

Mahsun. 2012. Metode Penelitian Bahasa. Jakarta: PT. Rajagrafindo Persada. 